Revista de Literatura, História e Memória

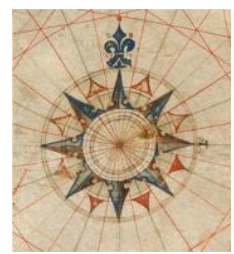

Dossiê: Manifestações de re-existência: a literatura em tempos de repressão

ISSN 1983-1498

VOL. 16 - No 27 - 2020

U N I O E S T E / CA S C A V E L - p. 44-60

\title{
RELATO DE UMA BÁRBARA MORTE: HISTÓRIA E LITERATURA NO CORDEL "O PADRE HENRIQUE E O DRAGÃO DA MALDADE” DE PATATIVA DO ASSARÉ
}

Account of a barbaric death: history and literature in the narrative poem "O Padre Henrique e o Dragão da Maldade" by Patativa do Assaré

\author{
Carlos Augusto Pegurski ${ }^{1}$ \\ Rogério Caetano de Almeida ${ }^{2}$ \\ Marcelo Fernando de Lima ${ }^{3}$
}

RESUMO: O objetivo deste trabalho é analisar o poema de cordel "O Padre Henrique e o Dragão da Maldade", escrito por Patativa do Assaré sobre o assassinato de um padre pernambucano que integrou a resistência no pior período da repressão da ditadura civil-militar, logo após a publicação do AI-5. Buscamos traçar uma relação entre o texto e os aspectos históricos que fazem parte da reflexão trazida pelo autor. Para além de identificar os elementos literários, observamos como esses recursos são usados para que o poema consiga denunciar crimes praticados durante o regime ditatorial.

PALAVRAS-CHAVE: Literatura brasileira; História; Ditadura civil-militar; Patativa do Assaré.

ABSTRACT: The objective of this work is to analyze the narrative poem "O Padre Henrique e o Dragão da Maldade", written by Patativa do Assaré on the murder of a priest from the Brazilian state of Pernambuco who joined the resistance in the worst period of the repression of the civil-military dictatorship, shortly after the publication of AI-5. We seek to trace a relationship between the text and the historical aspects that are part of the reflection brought by the author. In addition to identifying the literary elements, we observe how these resources are used so that the poem can denounce crimes committed during the dictatorial regime.

KEYWORDS: Brazilian literature; History; Civil-military dictatorship; Patativa do Assaré.

\section{INTRODUÇÃO}

O objetivo deste artigo é analisar o cordel "O Padre Henrique e o Dragão da Maldade", do poeta cearense Patativa do Assaré, levando em consideração o contexto político em que foi posto em circulação: a vigência da ditadura civil-militar que impôs um regime de exceção no Brasil, com a instituição da tortura como sistema de repressão dos movimentos de

\footnotetext{
${ }^{1}$ Possui graduação em Gestão Pública pela UFPR/IFPR (2011), especialização em Planejamento e Governança Pública pela UTFPR (2013) e especialização em Literatura Brasileira e História Nacional (2019). É graduando em Administração no Centro Universitário UniDomBosco.

2 Doutor em Letras (USP), professor do Programa de Pós-Graduação em Estudos de Linguagens (PPGEL) da UTFPR em Curitiba.

${ }^{3}$ Doutor em Letras (UFPR), professor-adjunto da Universidade Tecnológica Federal do Paraná (UTFPR) Câmpus Curitiba, atuando no Departamento Acadêmico de Linguagem e Comunicação (DALIC), nas graduações em Letras e em Comunicação Organizacional e no Programa de Pós-Graduação em Estudos de Linguagens (PPGEL).
} 
oposição às decisões do governo central. Nesse período marcado por perseguição aos chamados "inimigos internos" do sistema, milhares de cidadãos foram presos, torturados e centenas assassinados nos porões da ditadura. Entendendo a cultura popular como um instrumento de consciência e de resistência, Patativa do Assaré rompeu o cerco da censura ao denunciar, por meio deste poema e no campo simbólico, a morte de um padre defensor da democracia, que foi assassinado no plano real.

Na primeira parte do texto, argumentaremos que o poema é uma obra imbuída de compromisso artístico, utilizando as convenções formais de um gênero da cultura popular, mas também uma narrativa histórica com a intenção de produzir o registro de uma época, sobretudo porque usa do estatuto da arte para gravar aquilo de que os documentos oficiais se eximiram na época. Nesse segmento, buscamos também relacionar a trajetória de Patativa do Assaré com a produção artística engajada de seu tempo, que, refletindo os anseios por mudanças que se espalharam pelo mundo depois do final da década de 1950, embaladas pelas revoluções da América Latina, passaram a entender a cultura popular como uma forma contra-hegemônica.

$\mathrm{Na}$ segunda parte, é feita a análise literária do cordel, dando importância às relações intertextuais estabelecidas tanto com a cultura nordestina, quanto com a religião e a história recente do país. Procuramos identificar na produção do eu-lírico quais foram os recursos pelos quais o texto ganha sentido e cumpre a tarefa a que se destina: forma, métrica, escolha e uso de palavras, repetições, definição de uma ética, dialogismo com o leitor, diálogo com outros textos.

Acreditamos que este cordel possui particularidades que o tornam especialmente interessante para a discussão proposta, além do fato de não haver produções acessíveis sobre ele nos meios de uso comum na comunidade acadêmica, como os repositórios online. Esperamos que esse trajeto possa contribuir para as reflexões do papel social da literatura diante das demandas populares, sobretudo na época em que estamos vivendo, em que a nostalgia autoritária de pequenos grupos faz reviver o pesadelo dos piores dias da ditadura que são denunciados pelo poeta nordestino.

\section{UM POEMA DE DENÚNCIA}

Antônio Gonçalves da Silva (1909-2002), conhecido como Patativa do Assaré, foi um poeta, cantor e compositor nordestino. Nascido em Assaré (Ceará) em 1909, cresceu em uma família pobre e auxiliou os pais no trabalho do campo. Em meio à rotina de agricultor, 
profissão que manteve até o fim, fazia versos e os apresentava em feiras e rádios da região. Lançou seu primeiro livro, Inspiração Nordestina, com 47 anos. Em 1967, a obra ganhou uma segunda edição, com o nome Cantos do Patativa - e novos livros foram lançados: Patativa do Assaré: novos poemas comentados (1970); Cante lá que eu canto cá (1978); Ispinho e fulô (1988) e Aqui tem coisa (1994). Seus poemas também foram publicados em livros coletivos.

O conjunto da obra de Patativa vai muito além dos textos em livro, pois seus poemas frequentemente eram compostos para registro em cordel ou performance oral - compostos para recitar em rádio, em feiras ou memorizados pelo poeta que, até sua morte, com 93 anos, era admirado por recordá-los integralmente. Isso é muito peculiar se considerarmos que apenas o texto "O Padre Henrique e o Dragão da Maldade" tem 381 versos.

A obra de Patativa tem como temas recorrentes elementos da realidade social do povo nordestino, marcado historicamente por uma brutal assimetria de classe, pela violência e pela exploração econômica. Essa preocupação com justiça social aparece em inúmeros poemas, como o cordel "A triste partida", popularizado com a musicalização de Luiz Gonzaga, cuja narrativa aborda o êxodo de uma família de retirantes; "Reforma agrária", soneto em que clama a necessidade de emancipação do país pelo acesso à posse da terra; "Prefeitura sem prefeito", em que critica a administração política local e, por tê-lo escrito, acabou sendo preso por alguns instantes; e "Brasi de cima e Brasi de baxo", que trata da desigualdade social e da possibilidade de superação das divisões de classe.

O poema “O padre Henrique..." foi publicado na obra Ispinho e Fulô, de 1988, mas foi escrito provavelmente em 1969, logo depois do assassinato do padre Antônio Henrique Pereira da Silva Neto, auxiliar direto do arcebispo Dom Hélder Câmara, uma das principais vozes de resistência contra a ditadura. Padre Henrique foi torturado e morto na cidade do Recife na madrugada de 27 de maio de 1969. O assassinato teria motivado um pedido especial de Dom Hélder a Patativa para que escrevesse o cordel (TAVARES; MANZATTO, 2014).

Outro fator que aponta essa temporalidade e possibilita a interpretação de que o cordel é uma resposta articulada ao assassinato é a opção de Patativa por adotar a expressão "dragão da maldade" no título e no corpo do poema. Além da possibilidade mais imediata de identificação com a figura de São Jorge, em 1969 o diretor Glauber Rocha lançava o filme $O$ Dragão da Maldade contra o Santo Guerreiro, que ganhou o prêmio de direção em Cannes e representa uma continuidade de Deus e o Diabo na Terra do Sol (1964). Antônio das Mortes, protagonista de ambas as tramas, é um assassino mercenário, o que possibilita a leitura de que o "dragão da maldade" poderia ser o matador de padre Henrique, podendo ser identificado com as estruturas de poder que garantem a perpetuação das desigualdades sociais no Brasil. 
Essa interpretação se coaduna com a tônica geral da obra de Patativa, vinculada a um projeto que encara a cultura como um esteio da resistência popular. Segundo Tavares e Manzatto (2014), na crítica social do poeta é possível identificar uma opção pelos pobres (em alusão à Carta de Puebla, da CNBB, de 1979), evidenciada em sua participação em movimentos progressistas, nas Ligas Camponesas, na resistência à ditadura e nas campanhas pela Anistia e pelas Diretas. Em “O Padre Henrique...” é possível verificar essa tensão em vários momentos. O cordel aponta para uma ação de protesto mais geral, resgatando a compreensão de uma produção literária que se propõe a vocalizar discursos interditados. $\mathrm{O}$ assassinato do padre Henrique ocorreu meses depois do AI-5, ou seja, em um período de fechamento do regime e de supressão das liberdades democráticas; teve provavelmente, para além de silenciar o assassinado, o objetivo de ameaçar Dom Hélder Câmara. De toda forma, não era exceção, como relata o padre belga Jean Talpe no relatório da Comissão Nacional da Verdade $(2014, \text { p. } 175)^{4}$ :

Em 19 de fevereiro de 1969 fui sequestrado brutalmente por militares e levado à prisão. Aí já se encontrava o padre que morava comigo, preso uns dias antes e cruelmente torturado. Agora era minha vez de enfrentar a fúria dos carrascos. [...] Um amigo meu, professor da Universidade de São Paulo, foi pendurado de cabeça para baixo e assim, durante horas, batido com porrete e submetido a choques elétricos nas partes mais sensíveis do corpo. Uma moça, que ele não conhecia, teve de presenciar a cena e sofreu depois o mesmo tratamento vergonhoso na presença do meu amigo.

Isso é relevante para identificar qual é o caráter que Patativa dá a sua poesia. A literatura está a serviço do debate de projetos e ideias sociais. O envolvimento com os movimentos de contestação ao regime militar e, no campo da religião, sua simpatia com a teologia da libertação, permitem que consideremos essa interpretação.

Mas Patativa apresenta algumas pistas entre as estrofes que nos levam a considerar que seu texto acaba por cumprir outra tarefa: a do registro de ocorrências históricas. Um poema engajado, escrito em meio propício à divulgação, que, neste caso, é um poemadenúncia. $\mathrm{O}$ cordel encerra um registro que de outro modo seria difícil ocorrer. Isso se verifica de forma muito particular nos seguintes trechos (2005, p. 183 e 188. Grifos nossos):

E, por falar de injustiça traidora da boa sorte eu conto ao leitor um fato

\footnotetext{
${ }^{4}$ Além do padre Henrique, o relatório apresenta outros 16 casos de lideranças católicas assassinadas e desaparecidas entre 1969 e 1985, como Frei Tito e o estudante Honestino Guimarães; e, além do padre Jean, 17 casos de figuras expulsas ou banidas.
} 


\author{
de uma bárbara morte \\ que se deu em Pernambuco \\ famoso Leão do Norte \\ [...] \\ Rádio, TV e jornais, \\ nada ali noticiaram \\ porque as autoridades \\ estas verdades calaram \\ e o padre Antônio Henrique \\ morto no mato encontraram
}

O poema se inscreve na lacuna entre o fato e a ausência de registros e procura supri-la: "eu conto ao leitor um fato". Patativa assume a tarefa de inscrever-se na história por meio de um movimento de resistência. Apenas nos últimos anos, após a redemocratização, casos como este puderam ser recuperados. Entre as iniciativas, destacaram-se os trabalhos da Comissão Nacional da Verdade (CNV), além das matérias jornalísticas que informam à população os desdobramentos, como no seguinte trecho, de 22 de setembro de 2012.

Um dos símbolos vivos da repressão em Pernambuco, o ex-major da Polícia Militar José Ferreira dos Anjos afirmou em depoimento à Comissão Estadual da Verdade na quinta-feira que o empresário Roberto Souza Leão, morto há quatro anos, integrou o Comando de Caça aos Comunistas (CCC), que perseguia os opositores ao regime militar. O empresário, segundo ele, teria sido beneficiado financeiramente pela relação que mantinha com o expresidente general João Figueiredo (LACERDA, 2012).

O fato de que Patativa denuncia um episódio ocorrido em "Pernambuco/famoso Leão do Norte" e o empresário mandante do crime seja, segundo a $\mathrm{CNV}$, oriundo da região, cujo sobrenome é Leão, também nos orienta no sentido de compreender que o poema narra a trama do assassinato do padre Antônio Henrique. Ademais, o projeto Memórias da Ditadura, do Instituto Vladimir Herzog, que apresenta o trabalho feito pela CNV, confirma o silenciamento dos agentes públicos frente ao assassinato, que já havia sido denunciado por poema de Patativa:

[...] as investigações realizadas pela CEMDP, Comissão Estadual da Memória e Verdade Dom Hélder Câmara e Comissão Nacional da Verdade (CNV) encontraram indícios que permitem desconstruir a versão oficial de crime comum e indicar os agentes responsáveis pela execução. Os principais indícios advêm de um documento bastante esclarecedor: o informe confidencial no 685/70 do Serviço Nacional de Informações (SNI), de 1970 [...] nas quais afirmava que a execução de padre Antônio [Henrique] teria sido realizada por um grupo de jovens de extrema direita em coautoria com a polícia civil de Pernambuco, tendo inclusive sido usado carro pertencente à polícia civil no sequestro do padre. [...] Esses documentos revelam tanto a motivação política do crime quanto o fato de que as autoridades militares de 
Pernambuco e da esfera federal sabiam da autoria da execução e agiram para ocultar e interferir no processo, por meio do Ministério da Justiça. Em parecer confidencial enviado àquele ministério, consta que participaram do crime os investigadores da polícia civil Rível Rocha, Humberto Serrano de Souza, José Bartolomeu Gibson, Jerônimo Gibson e Rogério Matos. Os documentos produzidos pelo SNI, Ministério da Justiça e Cenimar desconstroem a versão oficial e comprovam a execução por motivação política perpetrada por integrantes do CCC e agentes policiais do estado de Pernambuco. Além disso, observa-se a subserviência do Ministério Público Estadual ao Poder Executivo Federal.

Há também relatórios e depoimentos da CNV que atestam uma simbiose entre o estado ditatorial e milícias, notadamente o CCC. Segundo esses relatos, o padre Henrique teria sido levado por uma caminhonete "Rural" verde e branca, pertencente ao Departamento de Investigação da Secretaria de Segurança Pública de Pernambuco, à época sob o comando de Bartolomeu Gibson; e que os reais assassinos do padre seriam, em vez de alguns jovens drogaditos atendidos no trabalho pastoral, jovens do CCC, inclusive um adolescente da família de Bartolomeu Gibson. Esse mesmo veículo teria sido usado em abril de 1969 em um atentado contra a sede do arcebispado, sob responsabilidade de Dom Hélder Câmara, e no assassinato do estudante Cândido Pinto, ocorrido no mês seguinte e denunciado no cordel de Patativa.

A compreensão do contexto político revela que o cordel "O Padre Henrique..." se inscreve como um poema-denúncia do assassinato e do tratamento conferido a esse caso pela mídia e pelas autoridades políticas, judiciárias e policiais. A partir disso, verificaremos quais são os instrumentos literários usados pelo eu-lírico para esse registro e de que forma eles colaboraram para a produção de sentido do poema como denúncia.

\section{ANÁLISE DO CORDEL}

Já observamos que "O Padre Henrique..." é rico em referências externas, dialogando com o papel social da igreja e das autoridades políticas e policiais e reivindicando uma série de relações com o cinema e outras fontes, além da própria natureza multimeio do cordel: entre literatura e oralidade, entre o texto e a xilogravura, entre a leitura e a performance. Cabe-nos, agora, analisar mais detalhadamente o texto, de forma a investigar como ocorre a produção de sentido proposta pelo poeta.

A forma do poema, como já apresentado, se dá na estrutura de cordel, gênero tradicional da Europa que se estabeleceu no Nordeste brasileiro. A Academia Brasileira de Literatura de Cordel (ABLC, 2018) aponta que, "oriunda de Portugal, a literatura de cordel 
chegou no balaio e no coração dos nossos colonizadores, instalando-se na Bahia e mais precisamente em Salvador. [...] Mais tarde, por volta de 1750, é que apareceram os primeiros vates da literatura de cordel oral". Por sua vez, Quintela (2005, p. 45-46) entende que é possível que publicações iniciais de clássicos europeus tenham dado surgimento à prática do cordel no Brasil, no entanto, a ampliação de sua popularidade se deve mais às possibilidades tecnológicas que se estabelecem nesse período em locais em que, junto a isso, resiste uma tradição de cultura oral.

Dentre as modalidades de métrica, a ABLC aponta a existência de uma variedade de possibilidades de arranjos: de quatro versos, sextilhas (podendo ser abertas, fechadas, soltas, corridas ou desencontradas), sextilhas, oitavas, décimas, martelo agalopado (liberdade de versos nas estrofes), galope à beira-mar (onze sílabas) e meia quadra (quinze sílabas). $\mathrm{O}$ cordel "O Padre Henrique..." se configura com sextilhas e redondilhas maiores. Contém 63 estrofes: 62 tem seis versos e uma estrofe apresenta dez, ao reproduzir livremente um trecho do poema "O Navio Negreiro", de Castro Alves. À exceção dessa estrofe, a métrica padrão auxilia na produção de um sentido de continuidade à história, o que é fundamental em se tratando de um poema narrativo - e reforça o sentimento de simplicidade e ordem natural apontada pelo eu-lírico.

Embora não haja marcações no texto, dividiremos o poema em quatro seções para facilitar a análise. Na primeira seção, com dez estrofes, o eu-lírico se apresenta e aborda o objetivo do poema. O eu-lírico evoca a si e ao seu ofício um conjunto de qualidades morais que estabelecem de início um pacto com o leitor em relação ao juízo sobre a narrativa a ser apresentada. Elas se referem a estar próximo à natureza ("sou um poeta do mato/vivo afastado dos meios"); ser um trabalhador humilde ("sou caboclo nordestino/tenho a mão calosa e grossa/a minha vida tem sido/da choupana para a roça"); ter compromisso com a verdade ("canto a noite de São João/com toda sua alegria/e canto o pobre que chora/pelo pão de cada dia"); ter fé ("primeiro peço a Jesus/uma santa inspiração"); e pautar-se por um senso de justiça ("falar contra as injustiças/foi sempre um dever sagrado/este exemplo precioso/Cristo deixou registrado/por ser reto e justiceiro/foi no madeiro cravado").

Nessas primeiras dez estrofes que montam a primeira seção, há nove conjugações dos verbos cantar e contar (dada a particularidade do cordel, operam como sinônimos do fazer poético). Essas inserções são relativas à tarefa de cantar ou contar a vida tal como ela é, como um compromisso de fé em relação à injustiça. Ao longo do poema, vai se manifestar diversas vezes o compromisso com os "pobres", "injustiçados", "humildes”, “fracos”, "pequenos", "desamparados" e "oprimidos". 
É perceptível que, para o eu-lírico, aquilo que é pertinente à natureza é bonito, simples e prazeroso, de forma que a experiência do eu-lírico com a natureza é marcada por essa relação de bem-estar e de pertencimento. Haveria uma forma de bem-viver na simplicidade do eu-lírico e de seu mundo, como na festa de São João, sem que haja nessas festividades uma quebra com a ordem natural porque popular. De outra parte, as relações sociais e as condições da vida humana seriam duras, ásperas, porque derivadas de relações de exploração:

Canto da mata frondosa
a sua imensa beleza
onde vemos os sinais
do pincel da Natureza
e quando é preciso eu canto
a mágoa, a dor e a tristeza
Canto a noite de São João
com toda sua alegria
sua latada de folha
repleta de fantasia
e canto o pobre que chora
pelo pão de cada dia
Canto o crepúsculo da tarde
e o clarão da linda aurora
canto aquilo que me alegra
e aquilo que me apavora
e canto os injustiçados
que vagam no mundo afora

No fim dessa primeira parte, o eu-lírico anuncia que vai narrar uma "penosa verdade": um seguidor de Cristo morrera nas mãos de malfeitores por defender os humildes. Esses malfeitores são nomeados como o Dragão da Maldade, figura que aparece desde o título do cordel. É possível que Patativa recupere a figura do dragão por algumas razões. Primeiro, parece apontar o uso de um elemento narrativo que já goza de uma valoração no tecido social. Isso facilita as identificações do leitor com a estrutura bem versus mal e estabelece transições entre particular e geral: investe no antagonismo do eu-lírico uma figura mítica, que opera como um símbolo transcendente ao caso particular, mas que guarda relações com o concreto. É possível, por exemplo, apontar relações entre o dragão e a forma com que o padre foi assassinado (arma de fogo), que aponta para o elemento dominado pelo dragão.

Em segundo lugar, existe a possibilidade já apresentada de diálogo com o Cinema Novo, reforçada pela data do assassinato, que coincide com o lançamento de $O$ Santo Guerreiro contra o Dragão da Maldade. Dessa forma, Patativa exploraria o filme, sobretudo na hipótese de a redação do cordel ser próxima ao lançamento do filme, relacionando o padre 
a um santo guerreiro e por oposição seus adversários com o "dragão da maldade". O uso de uma alegoria comum com a proposta fílmica é pertinente também porque o cineasta apresenta uma preocupação política relacionada à libertação do país desde o sertão, recuperando elementos populares nordestinos, inclusive a própria literatura de cordel.

Foi nesse sentido que Glauber Rocha apresentou as figuras típicas do imaginário do sertão brasileiro como o dragão, símbolo barroco da desmedida natureza e do desarmônico, e de São Jorge, símbolo da guerra e da caça (BUENO, 2009, p. 4). Ademais, esse resgate aponta para o terceiro ponto, em que se destaca o sentido religioso do símbolo, importante para o corpo discursivo do poema. É através dessa dimensão que ocorre a apresentação da trama.

Com o título do poema se depreende que "o Padre Henrique e o Dragão da Maldade" constroem o cenário de uma realidade valorada moralmente com grande teor religioso. As virtudes morais, naturais e religiosas se confundem. Nesse caso, o dragão pode ser sugerido como símbolo que configura o padre como mártir. Morat (2013, p. 3803) recorda que "para as primeiras gerações cristãs, o dragão representa a incorporação do princípio do mal. [...] São bastante difundidas as representações nas quais o dragão é vencido pelo arcanjo Miguel, por São Jorge ou por Cristo”. O autor acrescenta que diversas vezes a história de São Jorge foi usada com a finalidade de tornar acessíveis a públicos leigos os elementos gerais de um conto pela igreja, sobretudo por franciscanos e dominicanos, que possuíam elevado conhecimento teológico mas se preocupavam com a permeabilidade do conhecimento (MORAT, 2013, p. 3799).

Em outro eixo de leitura, o uso da figura Dragão da Maldade permite que a indeterminação do símbolo (quem é ou o que é o Dragão da Maldade?) possa ocupar tanto o lugar daquilo que não se sabe, como daquilo que, embora se saiba, não é permitido dizer, por razões políticas. E as características do dragão auxiliam nessa interpretação: uma figura desprovida de bondade, que maneja o fogo e classicamente opera como guardiã pode ser relacionada à força policial, sobretudo com a confirmação pela Comissão Nacional da Verdade do envolvimento de agentes dessa instituição na execução do religioso, ou mesmo da milícia apontada como executora (Comando de Caça aos Comunistas). A indeterminação do símbolo auxilia na argumentação.

E, por fim, Morat informa que o símbolo do dragão possui tradição no próprio cordel: há um poema tradicional chamado "Juvenal e o dragão", inspirado em São Jorge, escrito originalmente pelo pernambucano Leandro Gomes de Barros (1865-1918). Sua versão digitalizada mais antiga é datada do ano de 1974 e seu adaptador e ilustrador são artistas 
radicados na cidade do Recife, local do assassinato do padre Antonio Henrique (MORAT, 2013). É significativo também que, nessa história, Juvenal não seja cangaceiro, como ocorre no filme de Glauber Rocha e como seria mais óbvio para um soldado sertanejo. Em vez disso, é um camponês. Essa figura aproxima o eixo bem versus mal apresentado pelo eu-lírico do ponto de vista religioso e classista, coincidindo com a matriz epistemológica da Teologia da Libertação ${ }^{5}$, corrente teológica professada pelo padre.

A segunda seção do texto, com 21 estrofes, relata detalhes factuais da tortura seguida de assassinato do Padre Antonio Henrique: após ameaças de morte a pessoas ligadas a Dom Hélder Câmara, o padre Antonio Henrique fora assassinado barbaramente em 27 de maio de 1969, com 29 anos, apenas três anos após sua ordenação; seu corpo foi encontrado com marcas de bala, de facada e de estrangulamento, apontando tortura.

No decorrer da apresentação, o eu-lírico continua a se valer de uma polarização moral com fundamento religioso: "tinha três anos de padre/depois que ele se ordenou/pregava a mesma missão/que Jesus Cristo pregou/e foi por esse motivo/que o dragão lhe assassinou". O motivo da perseguição contra o padre seria o fato de o corpo da igreja estar "conscientizando os jovens/sobre os problemas da vida".

Para uma visão religiosa, chama a atenção que se trata de uma percepção de que a vida possui uma dimensão de resolução terrena. Não se trata de delegar a vida a alguma categoria transcendente, mas assumir suas contradições no aqui-agora, algo que o eu-lírico reivindica para a igreja: "mas o ministro de Deus/possui o santo dever/de estar do lado dos fracos/sua causa a defender/não é só salvar a alma/também precisa comer"; "a igreja de Jesus/nos oferece orações/mas também precisa dar/aos humildes instruções/para que possam fazer/suas reivindicações".

Patativa contextualiza o crime em panorama de perseguições que a igreja pernambucana vinha sofrendo, como acusações contra D. Helder Câmara e cartas e telefonemas anônimos que ameaçavam o assassinato de até 30 pessoas ligadas a ele. Para o eu-lírico, isso ocorria porque os religiosos, ligados a termos como fraternidade, paz, fé, amor, esperança, verdade e bem, atuavam em prol da população, descrita como humilde, possuidora de direitos humanos e fraca. De outro lado, poderosos são descritos em termos opostos: fúria, maldade, rancor, mentira - conjunto de características que seria mobilizada contra os líderes que ensinavam as verdades de Jesus.

\footnotetext{
5 Trata-se de uma corrente teológica católica progressista que surgiu na América Latina oficialmente em 1971, embora sua atuação seja anterior, principalmente na década de 1960. Partindo dos ensinamentos de Cristo, ela tem como premissa a ideia de que a igreja deve lutar contra as injustiças econômicas, políticas e sociais que atingem a população mais pobre.
} 
Chama a atenção que, até esse ponto do poema, o eu-lírico enaltece a população simples e humilde, como uma extensão do que é bom e natural, mas a classifica como fraca e oprimida e não dá maior centralidade a ela senão como objeto abstrato a ser amparado. A cruzada moral ocorre entre aqueles que estão do lado do povo contra os poderosos e ambos se distinguem da massa inominada. Seriam os operadores morais do mundo, cada qual tendendo a um conceito de justiça e bem ou a um conceito de injustiça e mal.

O conceito de que haveria uma ordem harmônica, desde a natureza e também nas relações sociais fraternas, que seria perturbada pelas relações sociais de exploração, é novamente recuperada quando o poema apresenta: "a 27 de maio/o santo mês de Maria/no ano 69/a natureza gemia/por ver o corpo de um padre/morto sobre a terra fria". Nesse caso, o assassinato foi de tal forma criminoso que a própria ordem natural teria sido afetada e se confunde com o padre: é a natureza quem geme e fica fria, e não ele ${ }^{6}$.

Ainda nessa segunda seção há um relato importante, que ajuda na compreensão do cenário em que ele é escrito e publicado e o configura ainda mais como um poema-denúncia: o silêncio sobre a tortura e o assassinato do padre Henrique. O poema registra que "rádio, TV e jornais/nada ali noticiaram/porque as autoridades/estas verdades calaram”, apontando para um acordo posteriormente confirmado pelo trabalho da Comissão Nacional da Verdade.

Esses questionamentos sobre os acontecimentos sociais no contexto de ditadura militar tornam-se especialmente significativos porque o debate de modelo de produção e de arranjo social estava em aberto e a repressão do regime era rigorosa. Quando do assassinato do padre, havia apenas dez anos que Cuba fizera sua revolução socialista, a União Soviética era uma referência global de outra proposta de organização social do trabalho e havia um horizonte de levantes de regimes de esquerda a ocorrer nos anos seguintes, como a eleição de Allende no Chile e a revolução sandinista na Nicarágua, que abrem e fecham a década de 1970. Da mesma forma, havia e haveria nos anos seguintes uma série de golpes e contrarrevoluções, como ocorrera no Brasil em 1964.

A terceira seção do poema se dedica a esse debate mais geral de projeto social. Composta por 18 estrofes, o eu-lírico se afasta momentaneamente do detalhamento e formula reflexões contra o regime político, em defesa do setor progressista da igreja e do comunismo, dando agora mais centralidade a categorias sociais oprimidas: estudantes, operários, agricultores, índios, negros. Nesse momento, esses atores terão capacidade de agir.

\footnotetext{
${ }^{6} \mathrm{Na}$ Teologia da Libertação, existe um campo que procurava localizar o homem como parte da natureza e ambos como criação unitária de Deus, havendo portanto uma dimensão ecológica na teologia. Uma obra importante sobre o tema é BOFF, Leonardo. Ecologia: grito da Terra, grito dos pobres. São Paulo: Ática, 1995.
} 
Isso é percebido logo de início, quando o eu-lírico denuncia outros crimes políticos na cidade do Recife contra estudantes, como a invasão do DCE da PUC, o assassinato de Cândido Pinto e o sequestro e prisão do estudante Cajá, que teria sofrido esses ataques porque deixou de ser "carreirista" e foi taxado de comunista. E é nesse ponto que o eu-lírico questiona qual seria, afinal, o mal de ser comunista (ASSARÉ, 2005, p. 189-191):

\author{
Será que ser comunista \\ é dar ao fraco instrução, \\ defendendo os seus direitos \\ dentro da justa razão, \\ tirando a pobreza ingênua \\ das trevas da opressão? \\ Será que ser comunista \\ é mostrar certeiros planos \\ para que o povo não viva \\ envolvido nos enganos \\ e possa se defender \\ do jogo dos desumanos? \\ Será que ser comunista \\ é saber sentir as dores \\ da classe dos operários, \\ também dos agricultores \\ procurando amenizar \\ horrores e mais horrores \\ $[\ldots]$ \\ Mostrando a mesma verdade \\ de Jesus na Palestina \\ o movimento se estende \\ contra a opressão que domina \\ sobre os nossos irmãos pobres \\ de toda América Latina \\ $[\ldots]$ \\ Por este motivo a Igreja \\ nova posição tomou \\ dentro da América Latina \\ a coisa agora mudou, \\ o bom cristão sempre faz \\ aquilo que Deus mandou.
}

O eu-lírico apresenta a postura cristã como capaz de resolver os conflitos do mundo, na medida em que a verdade, o amor e a fraternidade geram boa organização social; e apresenta que é o mundo quem ilumina o caminho pastoral, na medida em que trabalhariam “em benefício das classes desamparadas". De alguma forma, essa é a solução ética da 
desordem do mundo estabelecida pela opressão dos poderosos.

E há ainda nesta terceira seção um recurso muito interessante usado por Patativa. O eu-lírico apresenta uma denúncia dos setores oprimidos pelo poder (pelo regime?): "pois vemos o estudante/pelo poder perseguido/operário, agricultor/o nosso índio querido/e o negro? Pobre coitado!/é o mais desprotegido" (2005, p. 192). A estrofe seguinte recupera a preocupação de Castro Alves e, imediatamente após, encerra-se a terceira parte do poema com a recuperação ipsis litteris de um trecho de "O Navio Negreiro" que dialoga com o mesmo senso de indignação e de angústia religiosa do eu-lírico: "Senhor Deus dos desgraçados/dizeime vós, Senhor Deus/se é mentira, se é verdade/tenho horror perante os céus..." Para o eulírico, portanto, o trabalhador comum é a versão contemporânea do escravo de outrora, recuperação possível porque seu estar-no-mundo é significado a partir de uma historicidade.

Havíamos dito que na terceira seção há um distanciamento do rigor factual, em que o eu-lírico aborda outras reflexões, de ordem mais geral. Esse parêntese é interrompido por essa estrofe de quatro versos, caracterizando uma quebra no ordenamento visual e rítmico do poema. Torna-se interessante, portanto, que após a inserção da estrofe de Castro Alves o eulírico se desculpe com o leitor: "se me desviei do ritmo/não queira se aborrecer", que é o ponto de início da quarta seção. O desvio do ritmo se refere ao parêntese feito nas últimas 18 estrofes da terceira seção ou ao desvio do ritmo do trecho inserido por empréstimo de Castro Alves. Ambos os entendimentos atendem a essa provocação do eu-lírico, que volta a dialogar com o leitor: "Mas agora lhe prometo/com bastante exatidão,/terminar para o amigo/esta triste narração/contanto tudo direito/sem sair da oração" - o termo oração volta a trazer um significado religioso à tarefa de narrar o mundo.

A quarta seção, com 14 estrofes, retoma a narrativa do assassinato, agora com detalhes do enterro do padre, emprestando-lhe o estatuto de mártir. Isso está presente nestas passagens: "o corpo do Padre Henrique/que morreu martirizado"; "a morte de um jovem padre/que pelos jovens morreu"; "foi receber no Céu/o que na terra ganhou"; "foi receber no céu/sua coroa de glória"; e "o padre Henrique é um mártir/que morreu pelo seu povo".

Nesse final, o cordel lança mão de um recurso recorrente nesse tipo de literatura que é o da repetição de um estribilho, comumente usado nos dois últimos versos de cada estrofe. No caso, Patativa retoma um hino religioso católico: "prova de amor maior não há/que doar a vida pelo irmão", que teria sido cantada no cortejo fúnebre. O estribilho fecha três estrofes do cordel, incluindo a estrofe que finaliza o poema.

Como encadeamento do final, o cordel dá um sentido de continuidade ao padre (que recebe no céu as glórias merecidas) e à igreja: 


\author{
Prezado amigo leitor \\ Esta dor é minha e sua \\ De ver morrer Padre Henrique \\ De morte tirana e crua \\ Porém a igreja dos pobres \\ Sua luta continua
}

Nesse momento, a analogia a São Jorge é usada com um deslocamento: em vez de um mártir que matou um dragão, trata-se de um mártir cujo dragão ainda não foi vencido. $\mathrm{O}$ provável assassino e o provável mandante do assassinato não foram identificados, julgados e condenados, posto que o arranjo do estado de exceção orquestrou um silenciamento, e a ordem de exploração permanece vigente. Dessa forma, a luta por outra ordem social continua no horizonte da "igreja dos pobres".

\title{
CONSIDERAÇÕES FINAIS
}

Trinta e cinco anos após a redemocratização do país, é forçoso reconhecer que ainda temos dilemas em aberto do ponto de vista democrático. Sob diversos pontos de vista, a Constituição não foi ainda capaz de garantir uma cultura democrática - talvez esteja aí um debate importante sobre a contribuição da arte e dos meios de debate social não formais, ou não jurídicos, no que se refere à fundação dos marcos civilizatórios mínimos.

A literatura possui um papel importante de registro histórico no Brasil. O país construiu suas primeiras universidades apenas a partir do século XX, quando, na República recém-proclamada, o projeto de país foi objeto de debate de intelectuais. Esse descompasso na elaboração de um pensamento metódico em relação a outros países, mesmo entre os vizinhos da América Latina, colocou sobre a literatura por séculos a tarefa de um pensamento crítico, a formulação sobre os projetos de país e mesmo uma interpretação nacional.

Embora não exista um consenso na crítica sobre o lugar e a validade desse papel político, havendo até mesmo a impressão corrente de que obras politizadas possam ser panfletárias e de menor valor, porque comprometidas com outros horizontes que não aqueles estritamente "literários", o fato é que a literatura brasileira foi atravessada pelo contexto a que era submetida. Igualmente, cruzou esse contexto, influenciando os rumos do pensamento nacional.

Foi possível verificar com este trabalho como a produção literária foi imbuída de um debate de país que estava em aberto, procurando se inscrever nas disputas políticas sob os 
contornos que opunham democracia a estado de exceção. Partindo da hipótese de que o cordel teria sido escrito em 1969, Patativa ainda conviveria com 15 anos de ditadura, com uma produção literária que voltaria a esse eixo temático diversas vezes.

Para além das qualidades literárias do cordel, Patativa possuiu o mérito de narrar factual e simbolicamente um assassinato perpetrado por uma milícia paramilitar (Comando de Caça aos Comunistas), sob mando e financiamento de um empresário local, em acordo com as instituições estatais, como a polícia, o Ministério Público e o judiciário.

Foi impactante ao longo da análise acessar o registro da Comissão Nacional da Verdade e verificar os autos do crime narrado no cordel: fotos do corpo, do local e das armas, bem como detalhes e relatórios policiais e técnicos, como da autópsia. E essa história é tão recente, tão pouco conhecida, tão nossa.

Finalizadas as etapas de apresentação do contexto social de produção da obra e observação dos recursos utilizados no cordel para a obtenção dos resultados propostos, permitimo-nos agora a um balanço em tom mais valorativo.

Enquanto fazíamos o levantamento das informações para este artigo, o presidente da República eleito democraticamente ironizava o assassinato do pai do presidente da Ordem dos Advogados do Brasil $(\mathrm{OAB})^{7}$, militante contra o regime ditatorial, afirmando que poderia contar a verdade sobre o destino do corpo jamais encontrado. Antes disso, homenageara o militar torturador Carlos Alberto Brilhante Ustra no Congresso e dissera às mães de militantes desaparecidos que "quem procura osso é cachorro"8. Em outro momento, de revisão deste artigo para a publicação em meio à crise da pandemia do coronavírus, novamente nos deparamos com declarações abjetas.

O desencanto gerado pelo vácuo de debate político nos coloca diante de uma encruzilhada: não há mais amanhã redentor, mas o mundo se resolve agora, diante dos nossos olhos, com a beleza da condição humana e também o chorume que fomos capazes de produzir. Vivemos sob o risco de uma doença social que tende a automatizar nossa visão de mundo e infertilizar nossa esperança.

Em vez disso, precisamos nos assumir profundamente comprometidos, profundamente políticos, ainda que profundamente angustiados. Acreditamos que não podemos ter no pragmatismo e no egoísmo, filhos do desencanto, um projeto. Reconhecemo-nos como sujeitos no mundo e não acreditamos ser possível uma vida saudável e consequente sem

7 Disponível em: https://politica.estadao.com.br/noticias/geral,bolsonaro-e-a-oab-entenda-o-caso-sobre-adeclaracao-dada-pelo-presidente, 70002945773

8 Disponível em: https://revistaforum.com.br/noticias/bolsonaro faz troca_com desaparecidos_politicos/ 
enfrentar as questões sociais com a mesma seriedade com que enfrentamos, cada um de nós, nossas questões pessoais. Toda aposta de vida precisa do outro.

A literatura pode ser um caminho de formulação. A lucidez e a paixão com que aqueles que nos antecederam construíram suas obras como apostas de uma vida que valha a pena ser vivida podem nos dar pistas de como seguir em frente quando nos deparamos com abismos semelhantes ao que já foram enfrentados. Tomar a arte como espaço de emancipação pessoal e coletiva em tempos de desamparo de ideias é uma aposta imprescindível.

O cordel analisado neste trabalho é um pequeno exemplo de uma obra tensionada pelas agruras políticas do país. Escrita sob a ditadura, deu voz a setores sociais impossibilitados de um grito mais contundente. Em nossa análise, acreditamos que, em vez de subordinar a arte a determinados projetos, há grandeza em assumir um lugar histórico em períodos de conflito insuportável. Essa coragem é capaz de elevá-la. Inscrever pela literatura uma agenda social democrática que tem na dignidade humana um princípio é assumir sua dimensão mais valiosa. Quantos leitores não souberam do assassinato de um religioso vocacionado a um projeto popular a partir de varais de feiras no interior mais remoto?

E por que as forças militares não censuraram ou puniram Patativa, após seu relato? Esse lugar social do escritor, como um embaixador da liberdade, precisa ser garantido e dignificado. Há espaço para resistir e frutificar novas possibilidades de vida a partir da criação humana.

Se muitos derramaram sangue para que vivamos em um mundo democrático (ainda que uma democracia abalada, que questiona o limite da escolha popular para sua definição), outros tantos relataram um mundo autoritário assumindo riscos, emprestando sua biografia sob o maior dos riscos (e o maior dos amores): doar a vida pelo irmão.

A esses e essas lutadoras de canetas em punho, toda nossa admiração e nosso compromisso de uma vida de versos.

\section{REFERÊNCIAS}

ABLC. História do Cordel. Disponível em: http://www.ablc.com.br/o-cordel/historia-docordel. Acesso em: 18 jul. 2018. 18 jul. 2018.

Métricas. Disponível em: http://www.ablc.com.br/o-cordel/metricas-2. Acesso em:
ALVES,
Castro.
Navio
Negreiro.
Disponível
em: http://bd.camara.gov.br/bd/bitstream/handle/bdcamara/11874/navio negreiro_alves.pdf?seque 
$\underline{\text { nce }=4}$. Acesso em: 18 jul. 2018.

ANTONIO Henrique Pereira Neto (Padre Henrique). Memórias da Ditadura, 2018. Disponível em: http://memoriasdaditadura.org.br/memorial/antonio-henrique-pereira-netopadre-henrique/index.html. Acesso em 4 jul. 2018.

ASSARÉ, Patativa do. O Padre Henrique e o Dragão da Maldade. Disponível em: htt://docvirt.com/docreader.net/DocReader.aspx?bib=cordel\&pagfis=53890. Acesso em 4 jul. 2018 .

. O Padre Henrique e o Dragão da Maldade. Disponível em: http://catadoradeversos.blogspot.com/2012/12/o-padre-henrique-e-o-dragao-damaldade 6450.html. Acesso em 4 jul. 2018.

LACERDA, Angela. Ex-major cita empresário ligado à crime na ditadura. O Estado de São Paulo, 2012. Disponível em: https://politica.estadao.com.br/noticias/eleicoes,ex-major-citaempresario-ligado-a-crime-na-ditadura-imp-,934118. Acesso em: 4 jul. 2018.

MORAT, Camille. A linguagem simbólica de Gilvan Samico e a influência da obra de Eduardo Galeano na sua xilogravura. Disponível em: http://docplayer.com.br/130499487Universidade-federal-da-paraiba-universidade-federal-de-pernambuco-programa-de-posgraduacao-em-artes-visuais.html. Acesso em: 30 abr. 2020.

OLIVEIRA, Alysson. "O Dragão da Maldade" reestreia com cópias restauradas. Dom Total, 2008. Disponível em: http://domtotal.com/noticia/5503/2008/05/o-dragao-da-maldadereestraia-com-capias-restauradas/. Acesso em: 4 jul. 2018.

QUINTELA, Vilma Mota. O Cordel no fogo cruzado da cultura. Disponível em: https:// repositorio.ufba.br/ri/bitstream/ri/10956/1/Vilma\%20Mota\%20Quintela.pdf Acesso em 18 jul. 2018.

RELATÓRIO - Volume 2, Textos Temáticos. Comissão Nacional da Verdade, 2014. Disponível em: http://cnv.memoriasreveladas.gov.br/images/pdf/relatorio/Volume \%202\%20-\%20Texto\%204.pdf. Acesso em 4 jul. 2018.

TAVARES, Emerson Sbaderlotti; MANZATTO, Antonio. A opção pelos pobres na poesia de Patativa do Assaré. Revista Teoliterária, 2014, v. 4, n. 8. Disponível em: https://revistas.pucsp.br/index.php/teoliteraria/article/download/22741/16486. Acesso em: 4 jul. 2018. 